\title{
Article \\ Germination of Salicornia bigelovii (Torr.) under Shrimp Culture Effluents and the Application of Vermicompost Leachate for Mitigating Salt Stress
}

\author{
Emilio García-Galindo ${ }^{1}$, Alejandra Nieto-Garibay ${ }^{2, *(\mathbb{D})}$, Enrique Troyo-Diéguez ${ }^{2,3, *(\mathbb{D})}$, Gregorio Lucero-Vega ${ }^{4}$, \\ Bernardo Murillo-Amador ${ }^{2} \mathbb{E}$, Francisco Higinio Ruiz-Espinoza ${ }^{4}\left(\mathbb{D}\right.$ and Héctor Cirilo Fraga-Palomino ${ }^{2}$ \\ 1 Graduate Studies and Human Resources Program, Center for Biological Research of Northwest \\ México (CIBNOR), La Paz 23096, Mexico; egarcia@pg.cibnor.mx \\ 2 Arid Zone Agriculture Program, Center for Biological Research of Northwest México, La Paz 23096, Mexico; \\ bmurillo04@cibnor.mx (B.M.-A.); hfraga04@cibnor.mx (H.C.F.-P.) \\ 3 Mexican Society of Soil Science (SMCS), Chapingo 56230, Mexico \\ 4 Agronomy Academic Department, Baja California Sur Autonomous University (UABCS), \\ La Paz 23085, Mexico; g.lucero@uabcs.mx (G.L.-V.); fruiz@uabcs.mx (F.H.R.-E.) \\ * Correspondence: anieto04@cibnor.mx (A.N.-G.); etroyo04@cibnor.mx (E.T.-D.); \\ Tel.: +52-612-1238484 (ext. 3442) (A.N.-G.)
}

check for updates

Citation: García-Galindo, E.; Nieto-Garibay, A.; Troyo-Diéguez, E.; Lucero-Vega, G.; Murillo-Amador, B.; Ruiz-Espinoza, F.H.; Fraga-Palomino, H.C. Germination of Salicornia bigelovii (Torr.) under Shrimp Culture Effluents and the Application of Vermicompost Leachate for Mitigating Salt Stress. Agronomy 2021, 11, 424. https://doi.org/10.3390/ agronomy11030424

Received: 22 January 2021

Accepted: 22 February 2021

Published: 26 February 2021

Publisher's Note: MDPI stays neutral with regard to jurisdictional claims in published maps and institutional affiliations.

Copyright: (c) 2021 by the authors. Licensee MDPI, Basel, Switzerland. This article is an open access article distributed under the terms and conditions of the Creative Commons Attribution (CC BY) license (https:/ / creativecommons.org/licenses/by/ $4.0 /)$.

\begin{abstract}
Attenuators of salt-stress favor the use of effluents, being a low-cost organic product. The present study aimed to evaluate the effect of vermicompost leachate (VL) added to shrimpculture effluent on seeds and seedlings of Salicornia bigelovii (Torr.) under salt-stress, evaluating germination, water relations variables, and biomass. Seeds were irrigated with distilled water (DW) (CE: $0.0027 \mathrm{dS} \mathrm{m}^{-1}$ ), freshwater (FW) (CE: $1.36 \mathrm{dS} \mathrm{m}^{-1}$ ), seawater (SW) (CE: $55.83 \mathrm{dS} \mathrm{m}^{-1}$ ), shrimp residual water (SRW) (CE: $59.85 \mathrm{dS} \mathrm{m}^{-1}$ ), and with the same water sources but adding VL in 1:20 $v / v$. The means for the index of germination rate (IGR), germination energy (GE), and germination time (MGT) were higher with DW, DWVL, FW, and FWVL, decreasing with the others $(p \leq 0.05)$. In seedlings, the lowest water potential $(\Psi w)$ and osmotic potential $(\Psi s)$ were observed with SW, SWVL, SRW, and SRWVL ( $p \leq 0.05$ ), evidencing higher stress but the highest relative water content (RWC). The fresh and dry biomass increased and showed significant differences with SRW, and adding VL (DWVL, FWVL, SWVL, and SRWVL) acted as an effective attenuator of salt-stress. The response of water relations variables suggested an osmotic adjustment for mitigating the salt-stress in seedlings, lowering the $\Psi \mathrm{w}$ and $\Psi$ s but increasing the RWC.
\end{abstract}

Keywords: Salicornia bigelovii; halophyte; vermicompost; aquaculture effluent; organic crop; salt stress

\section{Introduction}

Salinity is a global scale problem affecting around 77 Mha of agricultural soils worldwide and around 20 to $33 \%$ of global irrigated land [1]. In Mexico, about $13 \%$ of agricultural soils are salt affected, mainly in the northern part of the country [2]. This situation has generated the need to explore crops with commercial agronomic traits that are capable of growing in saline environments, without compromising the use of fresh water [3].

Salicornia bigelovii (Torr.) is a halophyte plant that requires saline water during most of its lifecycle and is reported as a promising crop due to its multiple uses for human food [4], forage [5,6], and biofuel production [7]. S. bigelovii is distributed in North America, on the coastal areas of the Atlantic, the Gulf of Mexico, the Caribbean and the coast of South California and adjacent Mexico [8]. In Mexico, it is distributed along the coastal wetlands of Sonora and Baja California Sur, where plants are flooded for intermittent periods due to tidal flows [9]. It is considered as one of the most salt-tolerant halophyte plants due to its adaptation to seawater along its lifecycle $[4,10]$. This feature allows the use of residual seawater from aquaculture activities as an irrigation source for this novel crop. 
Marine and coastal aquaculture effluents contain a high amount of nutrients, organic matter, and salts which cause harmful effects to the environment when they are released untreated into the sea, causing different problems such as eutrophication, contamination, hypoxia, and loss of biodiversity [11,12]. Salicornia plant species have been used as a biofilter for aquaculture effluents allowing the use of the nutrients and minerals from these water sources and reducing the risk of contamination of marine ecosystems [13]. It is an obligate halophyte; however, it is prone to develop salinity stress during its early development stages when it is exposed to high-salinity irrigation water such as aquaculture effluents [14].

The effects of saline stress on crop growth and productivity are dependent on the duration, intensity, sensitivity, and the phenological stage of the target crop [15]. Germination and seedling stages are especially vulnerable to saline stress in halophytes [16]. Salt accumulation in the soil solution increases the osmotic pressure, reducing its water potential and radically limiting the absorption of water by seeds and seedlings [17]. As a physiology strategy, these plants develop different mechanisms, mainly an osmotic adjustment reducing the cellular water potential through the synthesis of compatible osmolytes, which favors the absorption of saline water [18]. Former studies about the osmotic adjustment have focused on different species of Salicornia $[19,20]$; however, such information is incipient for S. bigelovii, specifically during early life-cycle stages, germination and seedling emergence.

Organic fertilizers such as vermicompost leachate $(\mathrm{VL})$ are used in agriculture because they increase crop yields by improving the availability of nutrients for plants [21]. The presence of antioxidants, phytohormones, and humic acids has been reported in vermicompost leachates [22], contributing to attenuate the harmful effects of saline stress on seedlings [23]. A former study reported that the application of VL increased the growth of tomato seedlings by improving root development, total leaf area, number of leaves and stem thickness when submitted to saline stress by $\mathrm{NaCl}$ [24]. In this sense, it has been reported that the foliar application of VL in pomegranate seedlings reduced its $\mathrm{Na}^{+}$ concentration when $\mathrm{NaCl}$ treatments were applied, and also that chlorophyll degradation and oxidative stress diminished with it, suggesting its effect as an attenuating agent against salt stress [15]. At present, there is a lack of information about the use of VL to improve the germination and survival of $S$. bigelovii seedlings and to mitigate the effect of saline stress caused by marine aquaculture effluents.

The aim of this study was to evaluate the effect of VL on S. bigelovii seeds and seedlings under saline stress imposed by seawater aquaculture effluents. In this study, we investigated the use of different qualities of water and doses of VL to improve the germination and seedling stages of S. bigelovii.

\section{Materials and Methods}

\subsection{Study Site and Plant Material}

The experiment was carried out in the Center for Biological Research of Northwest México S.C. (CIBNOR) located north of the city of La Paz, Baja California Sur, Mexico with coordinates $24^{\circ} 08^{\prime} 10.03^{\prime \prime} \mathrm{N}$ and $110^{\circ} 25^{\prime} 35.31^{\prime \prime} \mathrm{W}$ (Figure 1).

S. bigelovii seeds were collected from September to October 2018 from mature plants located on the coast of Comitán, Baja California Sur, with coordinates $24^{\circ} 1^{\prime} \mathrm{N}$ and $110^{\circ} 2^{\prime} \mathrm{W}$, adjacent to CIBNOR. Mature plants were sundried for $72 \mathrm{~h}$ (Figure 2a), then grounded to obtain the dry biomass with the seeds. The separation of seeds from dry plant fragments was carried out by pouring $\sim 700 \mathrm{~mL}$ of distilled water into a beaker where the seeds that were deposited on the bottom by gravity were collected after $24 \mathrm{~h}$ (Figure $2 \mathrm{~b}$ ). Then, the seeds were dried at room temperature and sieved to select the largest seeds with uniform color and without apparent damage. Subsequently, they were sterilized by immersion in sodium hypochlorite (3\%) for $30 \mathrm{~min}$ and finally rinsed three times with distilled water. 


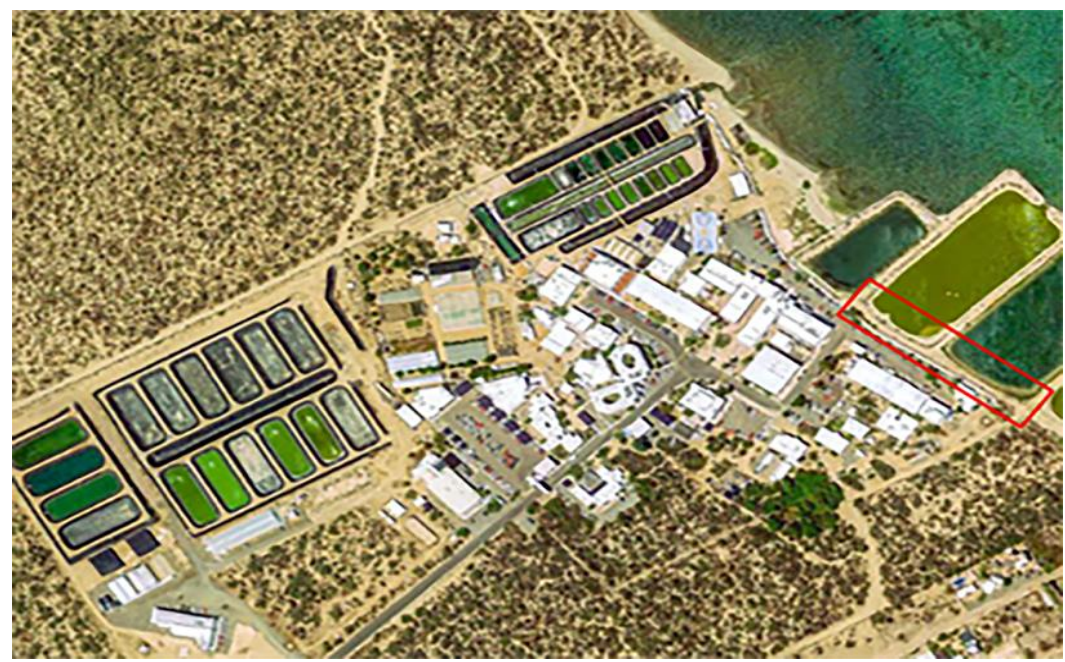

Figure 1. Satellite image from the Center for Biological Research of the Northwest México S.C. (CIBNOR), the red area indicates the seed collection area of Salicornia bigelovii (Torr.).

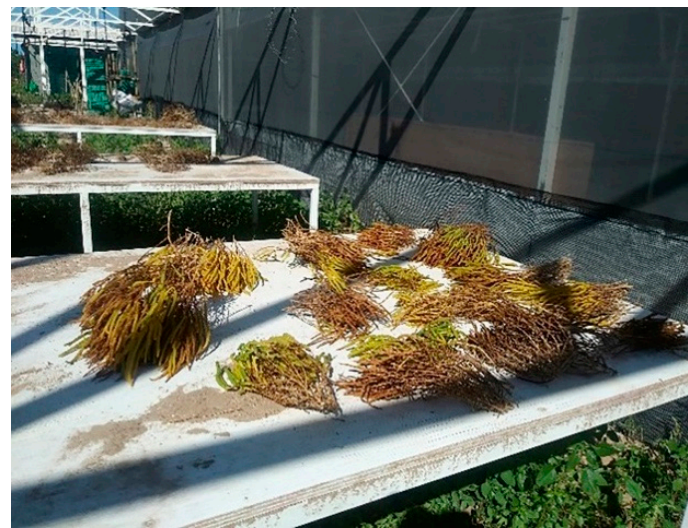

(a)

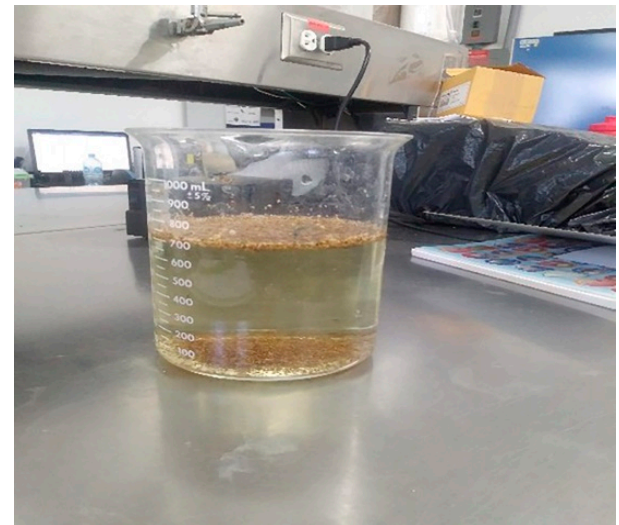

(b)

Figure 2. Sundried mature Salicornia bigelovii (Torr.) plants: (a) for seed separation, (b) at the CIBNOR Plant Physiology Technical Laboratory.

\subsection{Experimental Design}

The experiment was established under controlled conditions in a germination chamber (Lumistell, model IES-OS, series $1408-99-01$ ) at $25 \pm 1{ }^{\circ} \mathrm{C}$, with a relative humidity of $80 \%$, and a 12/12 h night/day photoperiod.

Eight treatments of different water quality sources were applied: (1) distilled water (DW) (CE: $0.0027 \mathrm{dS} \mathrm{m}^{-1}$ ), (2) freshwater (FW) (CE: $1.36 \mathrm{dS} \mathrm{m}^{-1}$ ), (3) seawater (SW) (CE: $55.83 \mathrm{dS} \mathrm{m}^{-1}$ ), (4) shrimp residual water (SRW) (CE: $59.85 \mathrm{dS} \mathrm{m}^{-1}$ ), and another group with the same water sources plus the addition of vermicompost leachates (VL) in a dilution 1:20 $v / v$ (volume). Watering was provided around every four days and $8 \mathrm{~mL}$ of treatment solution was added every time; although this was not always with high precision since evaporation was uneven in the Petri dishes, the added amount maintained a homogeneous volume. A total of 100 seeds were sown over filter paper circles (Whatman no. 4) in sterilized Petri dishes ISTA [25]. Every treatment was established with four replicates forming 32 experimental units, distributed under a completely randomized design.

The chemical composition of treatments was analyzed in the CIBNOR Water Quality Laboratory before the experiments started (Table 1). The electric conductivity (EC), total dissolved solids (TDS), salinity and $\mathrm{pH}$ were measured at the Edaphology Laboratory of CIBNOR with a portable conductivity meter Thermo Scientific (c) model Orion Star A222. Nitrates $\left(\mathrm{NO}_{3}{ }^{-}\right)$[26] and Nitrites $\left(\mathrm{NO}_{2}^{-}\right)$[27] were measured with a Lachat ion autoan- 
alyzer. Sulfates $\left(\mathrm{SO}_{4}{ }^{2-}\right)$ [28] were measured in a portable photometer HANNA model HI 96751 in the Water Quality Laboratory of CIBNOR. Calcium $\left(\mathrm{Ca}^{2+}\right)$, potassium $\left(\mathrm{K}^{+}\right)$, sodium $\left(\mathrm{Na}^{+}\right)[29]$ and phosphates $\left(\mathrm{PO}_{4}{ }^{-3}\right)$ [30] where measured in a portable photometer HANNA model HI83303 in the Plant Physiology Technical Laboratory of CIBNOR.

Table 1. Physico-chemical analyses of water quality variables of treatments.

\begin{tabular}{|c|c|c|c|c|c|c|c|c|c|c|c|}
\hline \multirow{2}{*}{ Treatments } & E.C. & TDS & Salinity & \multirow{2}{*}{$\mathrm{pH}$} & $\mathrm{NO}_{2}{ }^{-}$ & $\mathrm{NO}_{3}{ }^{-}$ & $\mathrm{PO}_{4}{ }^{3-}$ & $\mathrm{SO}_{4}{ }^{2-}$ & $\mathrm{Ca}$ & $\mathbf{K}^{+}$ & $\mathrm{Na}^{+}$ \\
\hline & $\mathrm{dS} / \mathrm{m}$ & ppt & psu & & & $\mu \mathrm{M}$ & & \multicolumn{4}{|c|}{$\mathrm{mg} / \mathrm{L}$} \\
\hline DW & 0.0027 & 0.0018 & 0.061 & 5.74 & ND & ND & ND & ND & ND & ND & ND \\
\hline DWVL & 0.87 & 0.348 & 0.164 & 6.57 & 0.952 & 849.05 & 12.4 & 42.75 & 52 & 6.2 & 36 \\
\hline FW & 1.36 & 0.669 & 0.728 & 8 & $<0.1$ & 416 & 0.481 & 58.9 & 114 & 5.8 & 240 \\
\hline FWVL & 1.84 & 0.894 & 0.967 & 8.33 & 1.150 & 1182.6 & 9.25 & 99.3 & 173 & 20 & 280 \\
\hline SW & 55.83 & 27.36 & 36.77 & 7.39 & $<0.1$ & 1.32 & 1.16 & 2181.8 & 480 & 6.2 & 3348 \\
\hline SWVL & 53.92 & 26.42 & 35.37 & 7.7 & 0.995 & 809.01 & 13.15 & 3250.9 & 400 & 20 & 3218 \\
\hline SRW & 59.85 & 29.33 & 38.7 & 6.88 & 63 & 1305.75 & 57.6 & 3013.6 & 348 & 17.1 & 3894 \\
\hline SRWVL & 58.98 & 28.9 & 38.06 & 6.91 & 98.5 & 2255.25 & 66.5 & 3600 & 192 & 20 & 3801 \\
\hline VL & 11.93 & 5.85 & 6.65 & 8.75 & $*$ & 1500 & * & $*$ & 110 & * & 640 \\
\hline
\end{tabular}

DW: Distilled Water. FW: Freshwater. SW: Seawater. SRW: Shrimp Residual Water. VL: Indicates the addition of vermicompost leachates. *: Not quantified. ND: None detected. $(n=3)$.

Vermicompost was produced at CIBNOR experimental field according to the methodology suggested by Acosta-Durán et al. [31]. The vermicomposting process was carried out in 200-L containers cut in half to which 5 holes were made in its base. Subsequently, a 5 -cm-thick layer of gravel and an anti-aphid mesh were placed to separate the gravel from the bed where the earthworms developed. Five kilograms of kitchen waste were used as food for the earthworms in the following proportions: banana peels $(25 \%)$, watermelon peel $(15 \%)$, papaya peel $(15 \%)$, coffee grounds $(15 \%)$, orange peel $(10 \%)$, cucumber peel $(10 \%)$, carrot peel $(5 \%)$, and tomato pieces $(5 \%)$. The kitchen waste was pre-composted for 21 days before being used as food for the earthworms. The feeding process was carried out using 5-cm-thick layers of pre-composted food every week for 12 weeks. A total of 400 adult Eisenia foetida earthworms were placed at the beginning of the feeding process. It was considered that the vermicomposting process ended when a homogeneous material was observed without the presence of remnants of the original material. At this point, the vermicompost was separated to be laid and sheltered in a dry place and away from light for 90 days for its mineralization.

Afterwards, VL were obtained according to the methodology described by Bidabadi et al. [15], where five kilograms of vermicompost were placed in a $10 \mathrm{~L}$ container to which five holes were made at the bottom with a $1 \mathrm{~mm}$ drill bit. Three liters of distilled water were poured into the bucket and then the leachate was collected in a container.

Physico-chemical analyses were made at the Edaphology Laboratory of CIBNOR (Table 2). EC, TDS, $\mathrm{pH}$, organic matter (O.M.), total nitrogen (TN), $\mathrm{NO}_{2}{ }^{-}, \mathrm{NO}_{3}{ }^{-}, \mathrm{P} \mathrm{Ca}^{2+}$ and $\mathrm{Mg}^{2+}$ were quantified, [32-36].

Table 2. Physico-chemical analyses of vermicompost; CIBNOR, La Paz BCS, México.

\begin{tabular}{|c|c|c|c|c|c|c|c|c|c|c|}
\hline \multirow{2}{*}{ Biomaterial } & EC & TDS & \multirow{2}{*}{$\mathrm{pH}$} & OM & $\mathbf{N}_{\text {total }}$ & $\mathrm{NO}_{2}^{-}$ & $\mathrm{NO}_{3}{ }^{-}$ & $\mathbf{P}$ & $\mathrm{Ca}^{2+}$ & $\mathrm{Mg}^{2+}$ \\
\hline & $\mathrm{dS} \mathrm{m}^{-1}$ & $\mathrm{~g} \mathrm{~L}^{-1}$ & & \multicolumn{2}{|c|}{$\%$} & \multicolumn{5}{|c|}{$\mathrm{mg} \mathrm{kg}^{-1}$} \\
\hline VC & 4.83 & 2.53 & 8.49 & 12.5 & 0.792 & 12.7 & 495.7 & 65.4 & 130.3 & 19,370 \\
\hline
\end{tabular}




\subsection{Germination Indices}

Germination was recorded daily after seeds were sown in Petri dishes. Seeds were considered germinated when hypocotyl reached a length of $2 \mathrm{~mm}$ (Figure 3).

$$
\begin{gathered}
\mathrm{GP}=(\text { No. of germinated seeds } / \text { No. of seeds }) \times 100 \\
\text { GRI }=(\mathrm{G} 1 / \mathrm{D} 1)+(\mathrm{G} 2 / \mathrm{D} 2)+\ldots(\mathrm{Gn} / \mathrm{Dn})
\end{gathered}
$$

where ' $G$ ' is the number of germinated seeds at day ' $\mathrm{D}$ '.

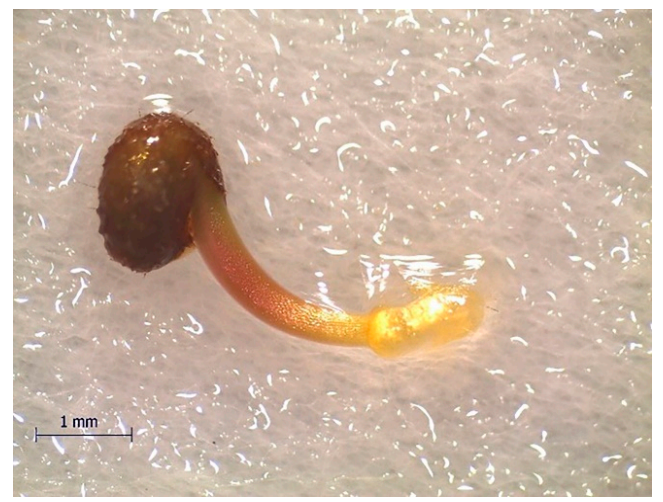

(a)

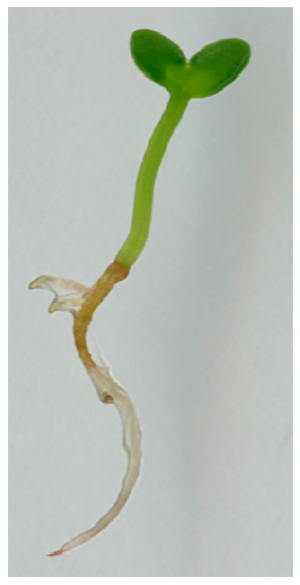

(b)

Figure 3. Germination images of Salicornia bigelovii seeds with FW: (a) 3 DAS, (b) 60 DAS.The germination percentage (GP) and the Germination rate index (GRI) at 20 days after sowing (DAS) were calculated according to Al-Mudaris [37] (Equations (1) and (2)).

The mean germination time was calculated according to Orchard [38] (Equation (3)).

$$
\mathrm{MGT}=\sum(\mathrm{N} \times \mathrm{D}) / \sum \mathrm{N}
$$

where ' $\mathrm{N}$ ' is the number of seeds germinated at day ' $\mathrm{D}$ ', and ' $\mathrm{D}$ ' is the number of days.

The germination energy is a mathematical method used as an indicator of the potential that a seed has to germinate [39] and was estimated according to the Maguire's expression [40] (Equation (4)):

$$
\mathrm{GE}=(\mathrm{N} 1 / \mathrm{D} 1)+(\mathrm{N} 2-\mathrm{N} 1) / \mathrm{D} 2+(\mathrm{Nj}-\mathrm{N} 1) / \mathrm{Dj}
$$

where ' $\mathrm{N}$ ' means the number of germinated seeds on the counting date, and ' $\mathrm{D}$ ' the number of days.

\subsection{Seedling Water Status Relations}

In order to determine the internal water status, the water potential $(\Psi w)$ was measured on healthy and uniform seedlings at the 20th day after sowing (DAS) using a Dewpoint Potential Meter model WP4-T (Decagon Devices Inc., Pullman, WA, US). Four readings per treatment were recorded using enough seedlings to complete a sample to cover the bottom of the sample cup/lids. Every reading corresponds to one sample; units are expressed in MPa. For the osmotic potential $\left(\Psi_{s}\right)$, a sample of $0.5 \mathrm{~g}$ of healthy $S$. bigelovii seedlings was collected from each treatment 20 DAS and transported to a deep freezer to maintain them at $-20^{\circ} \mathrm{C}$. Afterwards, the sage was extracted according to Mogahieb et al. [19], where samples were thawed and centrifuged at $1200 \times g$ for $25 \mathrm{~min}$ at $4{ }^{\circ} \mathrm{C}$. The osmotic potential of this stage was measured with a Wescor (Logan, UT, USA) Model 5500 Vapor Pressure Osmometer (VPO), using standards of known osmotic potentials for calibration. The disk filter papers used in the VPO equipment were saturated with the sage. A total of three 
readings per treatment were made. Data were recorded in $\mathrm{mmol} / \mathrm{kg}$ and transformed into $\mathrm{MPa}$ according to the van't Hoff equation [41] (Equation (5).

$$
\Psi_{S}=-C \times R \times T
$$

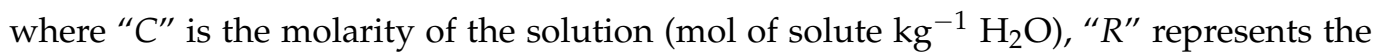
universal gas constant $\left(0.0831 \mathrm{~kg} \mathrm{MPa} \mathrm{mol}^{-1} \mathrm{~K}^{-1}\right)$, and " $T$ " the temperature (K).

The turgor potential was measured by subtracting $\Psi_{s}$ from $\Psi_{w}$, according to Mogahieb et al. [19].

The relative water content (RWC) was calculated according to the equation proposed by Yamasaki and Diellenburg [42] (Equation (6)) from complete and healthy seedlings 60 DAS.

$$
\mathrm{RWC}=(\mathrm{Fw}-\mathrm{Dw}) /(\mathrm{Tw}-\mathrm{Dw}) \times 100
$$

where, Fw is the fresh weight, Dw is the dry weight, and Tw is the turgent weight.

Fresh and dry weights were recorded using an analytical balance (Mettler Toledo, model AG204). Turgent weight was obtained from complete plants which were imbibed in distilled water until they reached a constant weight $(24 \mathrm{~h})$. Dry weights were registered after samples were dried in a pre-heated oven (Shel-Lab, model Fx-5, serie-1000203, USA) at $55^{\circ} \mathrm{C}$ until a constant weight was reached $(48 \mathrm{~h})$; four repetitions per treatment were measured.

\subsection{Seedling Biomass}

Because the analytical balance used in the present study was not able to record the dry biomass weight of seedlings at the 20th DAS, it was necessary to let the seedlings grow until the 60th DAS. Four seedlings per treatment were transported in individual paper bags to the laboratory for fresh (FB) and dry biomass (DB) recording using an analytical balance (Mettler Toledo, model AG204, USA). After fresh biomass recordings, seedlings were placed in a pre-heated oven (Shel-Lab, model Fx-5, serie-1000203, USA) at $55^{\circ} \mathrm{C}$ in each paper bag until they reached constant weight $(48 \mathrm{~h})$; four seedlings were used per treatment. Results were expressed in mg.

\subsection{Statistical Analyses}

Data were transformed to arcsine to meet the normality and homoscedasticity tests. A one-way ANOVA was performed to compare treatment means; Tukey HSD test $p \leq 0.05$ was used for mean significance separation. The statistical analyses were carried out with the software Statistica v. 10.

\section{Results}

\subsection{Effect of Vermicompost Leachate on the Physico-Chemical Properties of Treatments}

The addition of vermicompost leachates increased the electric conductivity (E.C.), total dissolved solids (TDS), and salinity for distilled water (DWVL), and freshwater (FWVL) treatments and decreased for treatments with shrimp residual water (SRWVL) and seawater (SWVL). The vermicompost leachate addition increased all treatments' $\mathrm{pH}$, except for SRWVL (Table 1). An increase in nitrates $\left(\mathrm{NO}_{3}{ }^{-}\right)$, phosphates $\left(\mathrm{PO}_{4}{ }^{3-}\right)$, sulfates $\left(\mathrm{SO}_{4}{ }^{2-}\right)$, and potassium $\left(\mathrm{K}^{+}\right)$was observed in treatments with the addition of $\mathrm{VL}$, where the highest value was recorded in SRWVL. Meanwhile, $\mathrm{Ca}^{+}$and $\mathrm{Na}^{+}$increased only for FWVL and DWVL and decreased for SWVL and SRWVL.

\subsection{Germination Percentage, Germination Rate, Mean Germination Time, and Germination Energy}

The germination percentage was affected by salt concentration from the water sources with high salinity treatments, with SRW, SRWVL, SW and SWVL registering less than the $50 \%$ of germination. Meanwhile, for distillate and freshwater treatments (DW, DWVL, FW and FWVL), the germination percentage was above $70 \%$ (Figure $4 \mathrm{~A}$ ). A $12 \%$ germination 
percentage increase was registered when VL was added in DW treatments, as shown by Tukey HSD analysis. A similar effect was observed for SRWVL, reflecting a germination percentage $13.3 \%$ higher than SRW. However, the germination percentage was not increased on FW and SW where VL was added (FWVL and SWVL). The highest germination percentage was registered for DWVL $(70 \%)$ and lowest on SRW (33\%). For the germination rate index, the maximum germination rate for DW, DWVL, FW and FWVL was registered in the first five DAS in comparison to the SW, SWVL, SRW and SRWVL, where it was reached on the seventh day (Figure 4B). The effect of the addition of VL was observed at the maximum germinated values reached along the days. For FW and FWVL, the maximum number of germinated seeds was registered on the third day (12 and 19, respectively). However, the addition of VL increased the number of germinated seeds by $37 \%$ compared to the treatment without it. DWVL registered the highest number of germinated seeds on the fifth day (14), compared to the DW whose maximum number of germinated seeds was 11 and was recorded on the sixth day. For SWVL, 10 fully germinated seeds were recorded on the seventh day; meanwhile, with SW, there were eight germinated seeds on the same day.
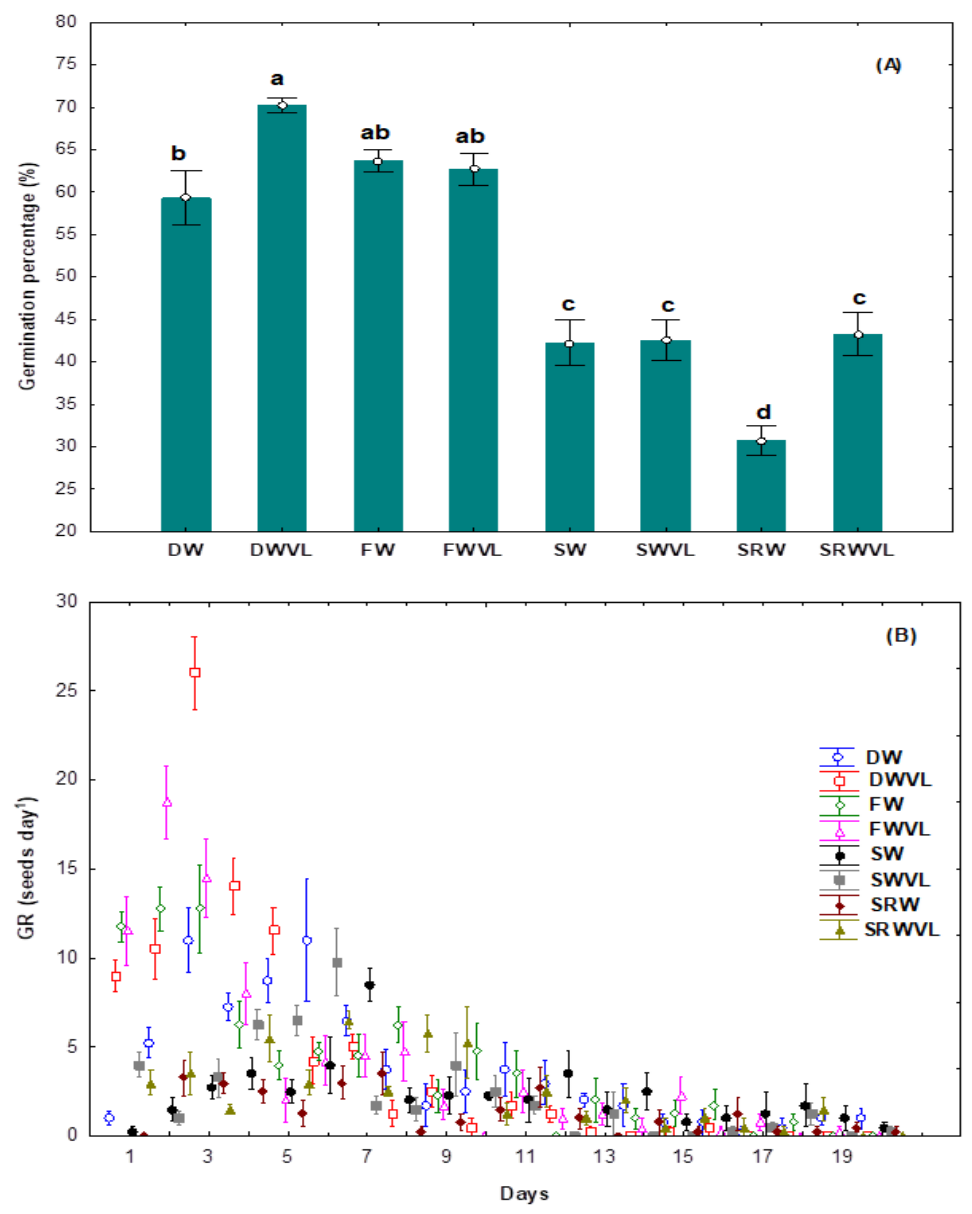

Figure 4. (A) Germination percentage of Salicornia bigelovii (GP), same letters above bars denote no-significant differences, and (B) germination rate (GR) of seeds under different water treatments; vertical lines at the top of bars $(\mathbf{A})$ and on the dots $(\mathbf{B})$ are the standard deviation $(n=4)$.

The germination energy (GE) showed the highest values for DWVL, FW and FWVL, being lower for DW, SWVL and SRWVL; the lowest values were recorded in SW and SRW. GE showed higher values when VL was added to the water sources (Figure 5A). The mean germination time (MGT) decreased in all treatments with VL. This index decreased in 2.7 days with DWVL, compared to DW and SRWVL (Figure 5B). 

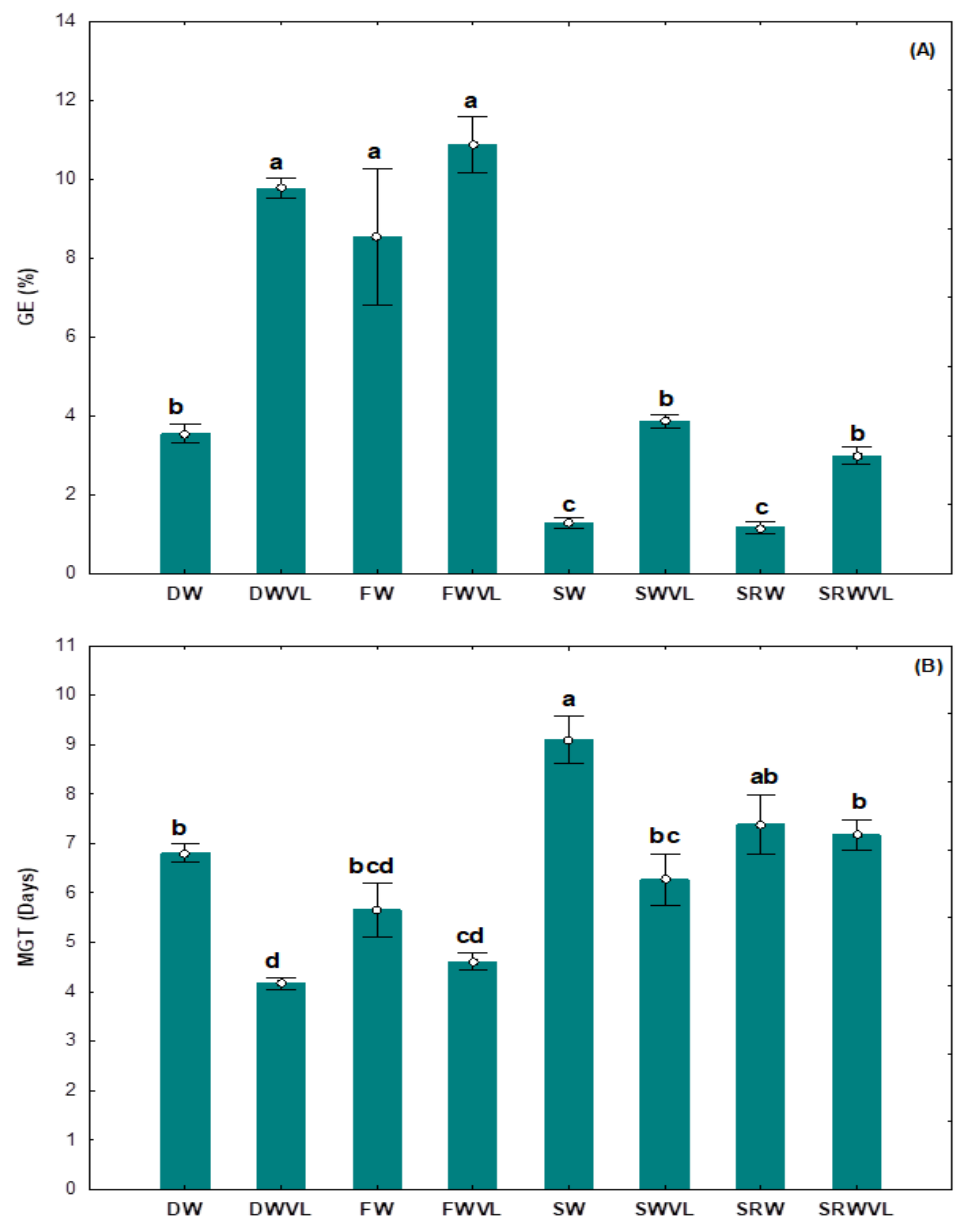

Figure 5. (A) Germination energy (GE), and (B) mean germination time (MGT) of Salicornia bigelovii germinated seeds under different water treatments. Same letters above bars denote no-significant differences; vertical lines at the top of bars are the standard deviation $(n=4)$.

The water potential $\left(\Psi_{w}\right)$ of seedlings was higher with treatments of low salinity (DW and FW) even when VL was added (DWVL and FWVL). Treatments under high salinity showed the lowest values of $\Psi_{w}$ (approximately $-2 \mathrm{MPa}$ ), in comparison to the low salinity treatments (DW, DWVL, FW and FWVL); at the same time, SRW reflected the lowest $\Psi_{w}$. The addition of VL to SW and SRW improved the values of $\Psi_{w}$ only in the second one (SRWVL) (Figure 6A). The osmotic potential $\left(\Psi_{S}\right)$ showed similar results as $\Psi_{w}$ (Figure $6 \mathrm{~A}$ ) for treatments with low salinity, even when VL was added (DW, FW, DWVL and FWVL) showing higher values than those with high salinity content (SW, SRW, SWVL and SRWVL). $\Psi_{S}$ decreased for SWVL and increased for SRWVL (Figure 6B). For the turgor potential $\left(\Psi_{t}\right)$, the effect of the addition of VL was observed in DWVL and SWVL treatments. For DW, the addition of VL (DWVL) decreased the $\Psi_{t}$ in 0.63 units. On the contrary, the addition of VL to SW (SWVL) increased the $\Psi_{t}$ values in one unit.

The application of VL generated a positive effect in the SWVL and SRWVL on the relative water content (RWC) according to the Tukey HSD test. The highest increase was registered in SWVL compared to SW with an increase of 20\% (Figure 6C). Data showed that seedlings under low salinity (DW, DWVL, FW and FWVL) registered less than $60 \%$ of their RWC compared to the high salinity treatments (SW, SWVL, SRW and SRWVL) whose values of RWC were over $60 \%$. 

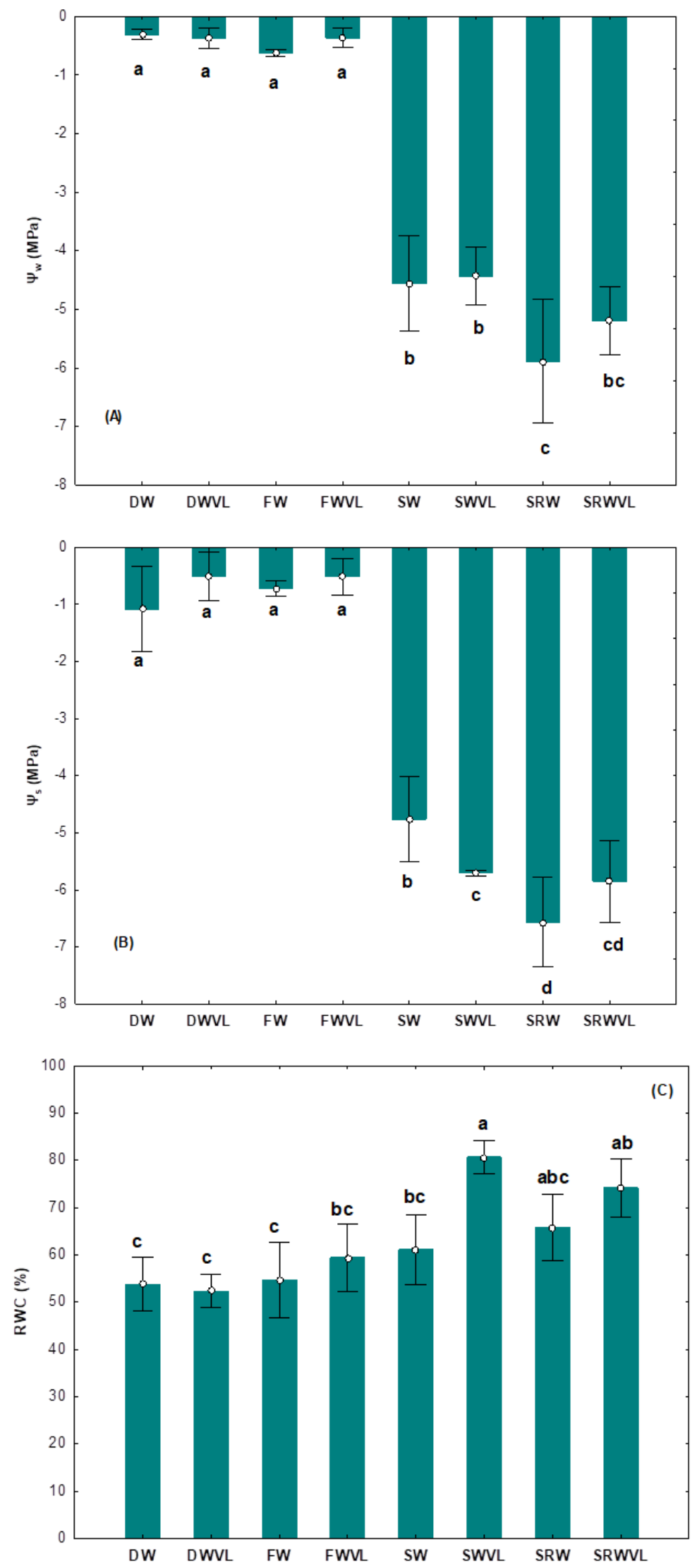

Figure 6. Water potential $(\Psi w)(\mathbf{A})$, osmotic potential $\left(\Psi_{S}\right)(\mathbf{B})$ and relative water content $(\mathrm{RWC})(\mathbf{C})$ of Salicornia bigelovii seedlings under different water treatments. Same letters above or below bars denote no-significant differences; vertical lines are the standard deviation $(n=4)$. 


\subsection{Seedling Biomass}

Fresh and dry seedling biomass showed significant differences. Lower fresh biomass values were observed in all treatments under high-saline conditions (SW, SWVL, SRW, SRWVL) compared to the low-saline ones (DW, DWVL, FW, FWVL). The fresh biomass production notoriously increased adding VL to FW (FWVL) compared to the same treatment without it (FW) (Figure 7A). For this variable, the best source of water was FWVL, registering the highest values, followed by DWVL $>$ SRWVL $>$ SWLV.
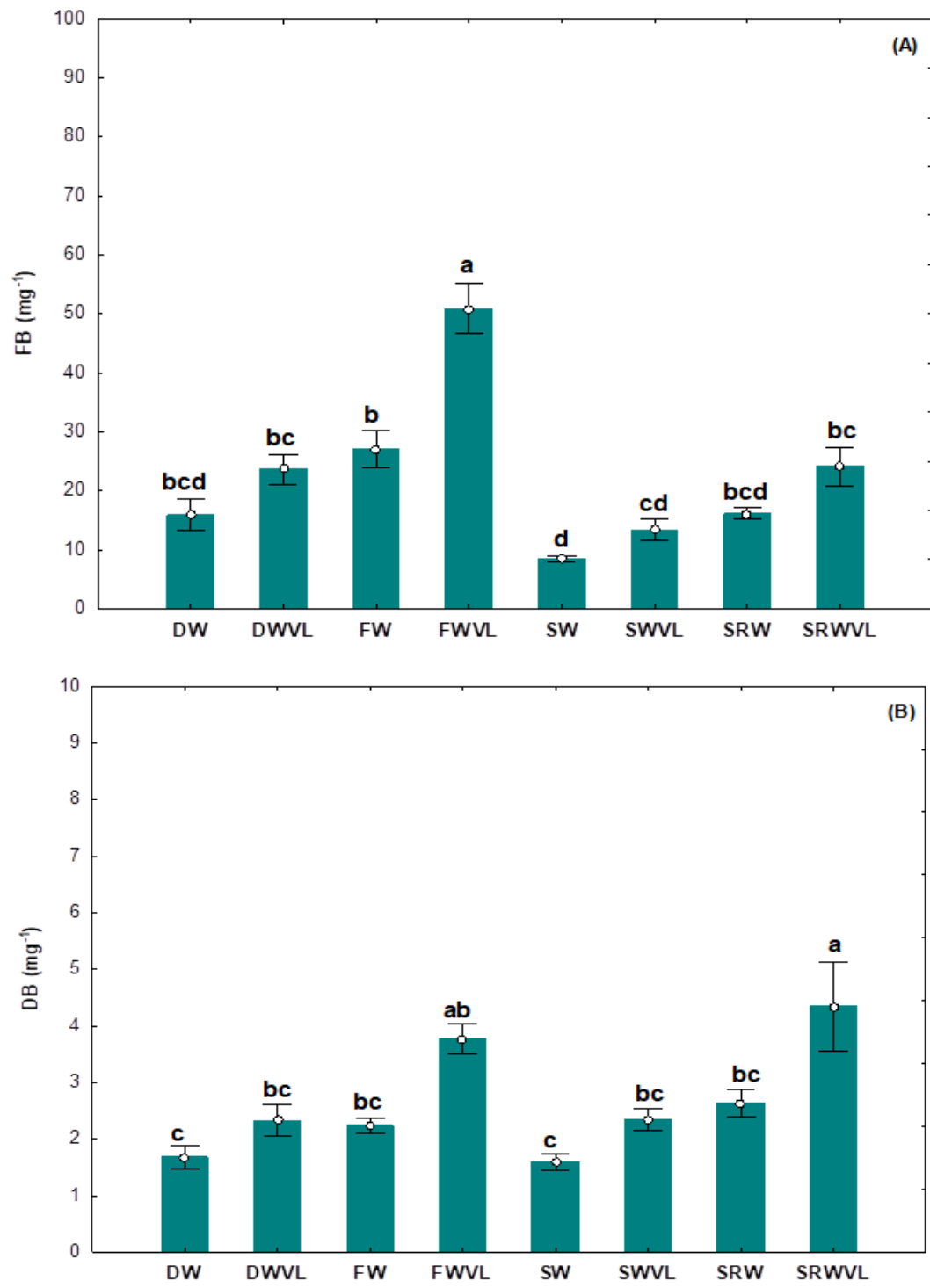

Figure 7. (A) Fresh biomass (FB), and (B) dry biomass (DB) of Salicornia bigelovii seedlings under different water treatments. Same letters above bars denote no-significant differences, vertical lines bars at the top of bars are the standard deviation $(n=4)$.

The data showed that treatments with VL promoted increases in dry biomass production, compared to the same treatments without its addition (Figure 7B).

\section{Discussion}

\subsection{Germination Indices}

Salicornia bigelovii germination was found to be a process favored by solutions with low salinity concentration, according to the results of the germination percentage in the DW and FW treatments compared to the SW and SRW which showed lower values. 
Similar results were reported for S. bigelovii [9], S. europaea [43] and S. rubra [16]. The low germination percentages registered in the SW and SRW treatments could occur due to the high concentration of solutes in both solutions, which increased the osmotic pressure in the medium, causing the development of water stress and inhibiting germination in both treatments, as mentioned by Guillén et al. [44]. This study quantifies the application of VL as an attenuating agent of salt stress on S. bigelovii seed germination.

The addition of VL increased the total germination of tomato seeds by $26.67 \%$ in response to $\mathrm{NaCl}$ treatments compared to the control group, but there was no meaningful measurement of natural saline conditions of shrimp culture effluents which include other salts, besides $\mathrm{NaCl}$ [23]. Results of the germination percentage for S. bigelovii seedlings using distilled water plus VL (DWVL), and shrimp residual water plus VL (SRWVL) improved in 12 and $13.3 \%$ of the total seed germination, respectively.

According to previous reports, VL contains auxins, cytokinins, gibberellins and brassinosteroids [22,45] which are phytohormones that play an important role in plant development and contribute to improving seed germination and emergence [46,47]. A stress-attenuating effect on the germination rate was detected when VL was added to the treatments and fewer days were needed to obtain a bigger number of germinated seeds, compared to treatments without VL. In this sense, an increase in germination rate of tomato and lettuce seeds under vermicompost tea treatments was reported, attributing its effects to the presence of hormones such as gibberellins, which induce the expression of the $\alpha$-amylase enzyme, responsible for the hydrolysis of starch reserves that are stored in the endosperm [48]. The transformation of starch into soluble sugars gives the embryo the necessary energy and vigor for the germination process [49,50]. Besides, improvement of the addition of leachate was more evident on germination energy where the number of fast-germinating seeds was considerably higher for treatments with VL.

\subsection{Seedling Water Status}

The obtained results showed that $S$. bigelovii seedlings with high salinity treatments (SW, SWVL, SRW, and SRWVL) developed less water and osmotic potential than seedlings under low salinity (DW, DWVL, FW, and FWVL). Similar results were reported for $S$. europaea [19] and S. persica [20] seedlings that were treated with a NaCl-salinity stress gradient, suggesting an increase in proline and glycine betaine synthesis and a greater accumulation of $\mathrm{Na}^{+}$within the cellular vacuole as well as a decrease in $\mathrm{K}^{+}$and $\mathrm{P}$ as salinity levels increased. They also reported that the development of an osmotic adjustment mechanism where proline and glycine betaine act as compatible osmolytes could protect different sensitive enzymes against these ions in the cytoplasm, in addition to using them as compatible osmolytes to reduce their total water potential and maintain their RWC. Under this context, the obtained results about the water status, osmotic potential and RWC variables evidence the development of an osmotic adjustment mechanism by $S$. bigelovii seedlings under high salinity levels. The synthesis of compatible osmolytes or the accumulation of inorganic ions within the cell vacuole deserve further investigations.

\subsection{Plant Biomass}

Results evidenced the decrease in the fresh biomass of $S$. bigelovii seedlings in the higher salinity treatments (SW, SWVL, SRW and SRWVL), compared to the low salinity treatments (DW, DWVL, FW and FWVL). Similar results were reported for S. bigelovii [51], S. europaea [19], and S. persica [20]. Results in the present study showed that the SRWVL treatment, despite being one of the highest salinity treatments, showed similar fresh weight biomass production values compared to low salinity treatments such as DW, DWVL and FW. Regarding the results in dry biomass production, the SRWVL treatment showed the highest values in this variable, followed by FWVL. It is noticeable that the high salinity treatments SRW and SWVL registered similar dry biomass production values in relation to low salinity treatments such as DWVL and FW, and even higher values compared to the lowest salinity treatment (DW). 
The application of $\mathrm{N}$ sources is necessary to improve the development of S. bigelovii [52], and in some cases, inorganic solutes contribute more than organic solutes to the osmotic adjustment, such as in S. brachiata (Roxb.) under natural saline conditions [53]. Such responses could explain the highest values registered in the fresh and dry weight biomass production of seedlings with the application of leachates, which contributed a greater amount of $\mathrm{N}$ as evidenced by the treatment analyzes (Table 1). Furthermore, VL holds a large amount of humic acids, which can promote plant growth [21], enhancing the absorption of nutrients [54]. Also, Canellas et al. [46] reported that humic acids isolated from earthworm compost improved maize plant development by favoring the ion transport across the root cell membranes, enhancing the $\mathrm{H}^{+}$-ATPase activity. This led to a higher electrochemical proton gradient in the soil solution favoring the plant nutrition. As previously discussed, the presence of different types of phytohormones in VL have been reported [22,23,55], which could come from the degradation of organic matter during the vermicomposting process due to the joint action between microorganisms and earthworms [45]. Among those, cytokinins and auxins are known to play important roles in several developmental processes such as chlorophyll production, shoot apical dominance and root development [56]. The points mentioned above could explain the highest fresh and dry biomass values registered when VL is used; however, further investigation is needed to elucidate these arguments.

It is clear that one of the most critical stages in the life cycle of halophytes is the period of germination and establishment [57], but in this sense, it is worth mentioning that the need to increase the productivity of halophytes may imply the indiscriminate use of fertilizers that can increase salinity. The results motivate detailed studies where composts or their leachates are combined with beneficial microorganisms or other biomaterials [58].

\section{Conclusions}

The obtained results contribute to reinforce the information on the susceptibility presented by S. bigelovii at high salinity levels during its germination and seedling development. However, salinity did not completely inhibit their germination. Water relations variables suggest the development of an osmotic adjustment strategy as a defense mechanism against saline stress by $S$. bigelovii seedlings.

The addition of VL showed an attenuation effect on the salt-stress, since the data analysis showed increases in fresh and dry biomass, as well as higher values in different germination indices such as the germination rate index, germination energy and mean germination time. However, its effect on increasing the germination percentage was clear with low salinity water and was not homogeneous with high salinity water sources.

The evidence suggests that adding VL to a water source improves germination and promotes increases in dry biomass production, but it is worth taking into account the saline quality of the water source to avoid depletion of the osmotic pressure in the soil solution and consequently in the plant tissues.

Finally, as vermicompost is a naturally processed manure which is becoming popular day by day, it is promising to consider in future studies that the combined use of vermicompost or vermicompost leachates with biochar may favor synergies that help minimize the impact of soil salinity on a range of crops.

Author Contributions: Conceptualization, E.G.-G., A.N.-G. and E.T.-D.; data curation, G.L.-V., F.H.R.-E. and H.C.F.-P.; formal analysis, E.G.-G., E.T.-D. and B.M.-A.; funding acquisition, E.T.-D. and B.M.-A.; investigation, E.G.-G. and A.N.-G.; methodology, G.L.-V., B.M.-A. and H.C.F.-P.; supervision, A.N.-G. and E.T.-D.; validation, A.N.-G. and F.H.R.-E.; visualization, E.T.-D. and B.M.-A.; writingoriginal draft, E.G.-G.; writing-review \& editing, A.N.-G. and E.T.-D. All authors have read and agreed to the published version of the manuscript.

Funding: This research was supported by the National Council of Science and Technology of México (CONACYT), and by the Water Consortium (Consorcio Agua-Conacyt), through the Project 0297116. The APC was funded by Project 4631 'Conacyt_-Problemas Nacionales 2017-I'.

Institutional Review Board Statement: Not applicable. 
Informed Consent Statement: Not applicable.

Data Availability Statement: Data is available for transparency at www.cibnor.gob.mx (anieto04@cibnor.mx, etroyo04@cibnor.mx) (accessed on 25 February 2021).

Acknowledgments: The authors thank Maria Del Carmen Mercado-Guido and Lidia Hirales-Lucero technician of the Plant Physio-Technical Lab at CIBNOR. Also, to the field Technicians Pedro Luna G., Saúl E. Briseño R., Adrián Jordán and José Raymundo Ceseña N. Financial and administrative support was given by the Project 0297116 "Cluster Bioturnosina", and by the Grupo Agua-Conacyt (Grupo GIA-Conacyt) based at CIMAV-Durango.

Conflicts of Interest: The authors declare no conflict of interest. Also, that the funders had no role in the design of the study; in the collection, analyses, or interpretation of data; in the writing of the manuscript, or in the decision to publish the results.

\section{References}

1. Hayat, K.; Bundschuh, J.; Jan, F.; Menhas, S.; Hayat, S.; Haq, F.; Shah, M.A.; Chaudhary, H.J.; Ullah, A.; Zhang, D.; et al. Combating soil salinity with combining saline agriculture and phytomanagement with salt-accumulating plants. Crit. Rev. Environ. Sci. Technol. 2019, 50, 1085-1115. [CrossRef]

2. Herrera-Romero, J.A.; Bojórquez-Serrano, J.I.; Can-Chulim, A.; Madueño-Molina, A.; García-Paredes, J.D. Salinity and soil properties of beach ridge in national marshlands in Mexico. Rev. Bio Cienc. 2019, 6, 1-14. [CrossRef]

3. Munns, R.; Gilliham, M. Salinity tolerance of crops-What is the cost? New Phytol. 2015, 208, 668-673. [CrossRef]

4. Ventura, Y.; Wuddineh, W.A.; Myrzabayeva, M.; Alikulov, Z.; Khozin-Goldberg, I.; Sphigel, M.; Samocha, T.M.; Sagi, M. Effect of seawater concentration on the productivity and nutritional value of annual Salicornia and perennial Sarcocornia halophytes as leafy vegetable crops. Sci. Hort. 2011, 128, 189-196. [CrossRef]

5. Glenn, E.P.; Coates, W.E.; Riley, J.J.; Kuehl, R.O.; Swingle, R.S. Salicornia bigelovii Torr.: A seawater-irrigated forage for goats. Anim. Feed Sci. Technol. 1992, 40, 21-30. [CrossRef]

6. Attia, F.M.; Alsobayel, A.A.; Kriadees, M.S.; Al-Saiady, M.Y.; Bayoumi, M.S. Nutrient composition and feeding value of Salicornia bigelovii Torr. meal in broiler diets. Anim. Feed Sci. Technol. 1997, 65, 257-263. [CrossRef]

7. Eganathan, P.S.R.; Subramanian, H.M.; Latha, R.; Srinivasa Rao, C. Oil analysis in seeds of Salicornia brachiata. Ind. Crops Prod. 2006, 23, 177-179. [CrossRef]

8. Kadereit, G.; Ball, P.; Beer, S.; Mucina, L.; Sokoloff, D.; Teege, P.; Yaprak, A.E.; Freitag, H. A taxonomic nightmare comes true: Phylogeny and biogeography of glassworts (Salicornia L., Chenopodiaceae). Taxon 2007, 56, 1143-1170. [CrossRef]

9. Troyo-Diéguez, E.; Solis-Cámara, A.M.B. Germinación de Salicornia bigelovii Torr. (Chenopodiaceae) bajo diferentes concentraciones de agua marina. Southwest. Nat. 1992, 37, 22-27. [CrossRef]

10. Glenn, E.P.; Miyamoto, S.; Moore, D.; Brown, J.J.; Lewis-Thompson, T.; Brown, P. Water requirements for cultivating Salicornia bigelovii Torr. with seawater on sand in a coastal desert environment. J. Arid Environ. 1997, 36, 711-730. [CrossRef]

11. Cao, L.; Wang, W.; Yang, Y.; Yang, C.; Yuan, Z.; Xiong, S.; Diana, J. Environmental impact of aquaculture and countermeasures to aquaculture pollution in China. Environ. Sci. Pollut. Res. 2007, 14, 452-462. [CrossRef]

12. Buhmann, A.; Papenbrock, J. Biofiltering of aquaculture effluents by halophytic plants: Basic principles, current uses and future perspectives. Environ. Exp. Bot. 2013, 92, 122-133. [CrossRef]

13. Webb, J.M.; Quinta, R.; Papadimitriou, S.; Norman, L.; Rigby, M.; Thomas, D.N.; Le Vay, L. Halophyte filter beds for treatment of saline wastewater from aquaculture. Water Res. 2012, 46, 5102-5114. [CrossRef]

14. Rueda-Puente, E.O.; Murillo-Amador, B.; Ortega-García, J.; Rangel-Preciado, P.; Nieto-Garibay, A.; Holguín-Peña, R.J.; LópezAhumada, G.A.; Rodríguez-Félix, F.; Vargas-López, J.M.; Wong-Corral, F.J. Desarrollo natural de la halófita Salicornia bigelovii (Torr.) en zona costera del estado de Sonora. Trop. Subtrop. Agroecosyst. 2017, 20, 1-9. Available online: http://www.revista.ccba. uady.mx/ (accessed on 2 December 2020).

15. Bidabadi, S.S.; Dehghanipoodeh, S.; Wright, G.C. Vermicompost leachate reduces some negative effects of salt stress in pomegranate. Int. J. Recycl. Org. Waste Agric. 2017, 6, 255-263. [CrossRef]

16. Khan, M.A.; Gul, B.; Weber, D.J. Seed germination in the Great Basin halophyte Salsola iberica. Can. J. Bot. 2002, 80, 650-655. [CrossRef]

17. Khan, M.A.; Gul, B. Halophyte seed germination. In Ecophysiology of High Salinity Tolerant Plants, 1st ed.; Khan, M.A., Weber, D.J., Eds.; Springer: Berlin/Heidelberg, Germany, 2006; pp. 11-30.

18. Khan, M.A. An ecological overview of halophytes from Pakistan. In Tasks for Vegetation Science, 1st ed.; Lieth, H., Moschenko, M., Eds.; Kluwer Academic Press: Dordrecht, The Netherlands, 2003; Volume 38, pp. 167-188.

19. Mogahieb, R.E.A.; Saneoka, H.; Fujita, K. Effect of salinity on osmotic adjustment, glycinebetaine accumulation and the betaine aldehyde dehydrogenase gene expression in two halophytic plants, Salicornia europaea and Suaeda maritima. Plant Sci. 2004, 166, 1345-1349. [CrossRef]

20. Aghaleh, M.; Niknam, V.; Ebrahimzadeh, H.; Razavi, K. Salt stress effects on growth, pigments, proteins and lipid peroxidation in Salicornia persica and S. erupaea. Biol. Plant. 2009, 53, 243-248. [CrossRef] 
21. Gutiérrez-Miceli, F.A.; Oliva Llaven, M.A.; Mendoza Nazar, P.; Ruíz Sesma, B.; Álvarez-Solís, J.D.; Dendooven, L. Optimization of vermicompost and worm-bed leachate for the organic cultivation of radish. J. Plant Nutr. 2011, 34, 1642-1653. [CrossRef]

22. Aremu, A.O.; Stirk, W.A.; Kulkarni, M.G.; Tarkowská, D.; Turecková, V.; Gruz, J.; Subrtová, M.; Pencik, A.; Novák, A.; Dolezal, K.; et al. Evidence of phytohormones and phenolic acids variability in garden-waste-derived vermicompost leachate, a well-known plant growth stimulant. Plant Growth Regul. 2015, 75, 483-492. [CrossRef]

23. Benazzouk, S.; Dobrev, P.I.; Djazouli, Z.E.; Motyka, V.; Lutts, S. Positive impact of vermicompost leachate on salt stress resistance in tomato (Solanum lycopersicum L.) at the seedling stage: A phytohormonal approach. Plant Soil. 2020, 446, 145-162. [CrossRef]

24. Chinsamy, M.; Kulkarni, M.G.; Van Staden, J. Garden-waste-vermicompost leachate alleviates salinity stress in tomato seedlings by mobilizing salt tolerance mechanisms. Plant Growth Regul. 2013, 71, 41-47. [CrossRef]

25. ISTA. International Rules for Seed Testing; ISTA: Zurich, Switzerland, 1999.

26. Bendscheider, K.; Robinson, R.J. A New Spectrophotometric Method for the Determination of Nitrite in Sea Water; Technical Report No. 8; Oceanographic Laboratories, University of Washington: Washington, DC, USA, 1952; Volume 183, pp. 1-18. Available online: https:/ / digital.lib.washington.edu/researchworks/bitstream/handle/1773/15938/52-1.pdf? sequence=1\&isAllowed=y (accessed on 26 November 2020).

27. Morris, A.W.; Riley, J.P. The determination of nitrate in sea water. Anal. Chim. Acta 1963, 29, 272-279. [CrossRef]

28. Chesnin, L.; Yen, C.H. Turbidimetric determination of available sulphates. Soil Sci. Soc. Am. J. 1950, 15, 149-151. [CrossRef]

29. Culkin, F.; Cox, R.A. Sodium, potassium, magnesium, calcium and strontium in sea water. Deep Sea Res. Oceanogr. Abstr. 1966, 13, 789-804. [CrossRef]

30. Valderrama, J.C. The simultaneous analysis of total nitrogen and total phosphorus in natural waters. Mar. Chem. 1981, 10, 109-122. [CrossRef]

31. Acosta-Durán, C.M.; Solís-Pérez, O.; Villegas-Torres, O.G.; Cardoso-Vigueros, L. Precomposteo de residuos orgánicos y su efecto en la dinámica poblacional de Eisenia foetida. Agron. Costarric. 2013, 37, 127-139.

32. Jackson, M.L. Soil Chemical Analysis; Prentice-Hall, Inc: Englewood Cliffs, NJ, USA, 1958; pp. 66-81.

33. NOM-021-SEMARNAT. Que Establece las Especificaciones de Fertilidad, Salinidad y Clasificación de Suelos. Estudios, Muestreo y Análisis. Ministry of the Environment and Natural Resources (Secretaria de Medio Ambiente y Recursos Naturales), 2nd ed.; Federation Official Gazette (Diario Oficial de la Federación): Mexico City, Mexico, 2000; pp. 12-13. Available online: http:/ / www.ordenjuridico.gob. $\mathrm{mx} /$ Documentos/Federal/wo69255.pdf (accessed on 26 November 2020).

34. Bremner, J.M. Total Nitrogen. Methods of Soil Analysis; American Society of Agronomy: Madison, WI, USA, 1965; pp. 1091-1100.

35. Strickland, J.D.H.; Parsons, T.R. A Practical Handbook of Seawater Analysis, 2nd ed.; Fisheries Research Board of Canada Bulletin: Ottawa, ON, Canada, 1972; p. 310.

36. Jackson, M.L. Análisis Químico de Suelos; Ediciones Omega: Barcelona, Spain, 1976; pp. 283-301.

37. Al-Mudaris, M.A. Notes on various parameters recording the speed of seed germination. J. Agric. Trop. Subtrop. 1998, 99, 147-154. Available online: https://www.jarts.info/index.php/tropenlandwirt/article/view/1495/671 (accessed on 14 December 2020).

38. Orchard, T.J. Estimating the parameters of plant seedling emergence. Seed Sci. Technol. 1977, 5, 61-69.

39. Wani, M.R.; Singh, S.S. Correlation dynamics of germination value, germination energy index and germination speed of Pongamia pinnata (L.) Pierre seeds of Pendra Provenance, Chhattisgarh, India. Int. J. Res. Agric. For. 2016, 3, $28-32$.

40. Maguire, J.D. Speed of germination-aid in selection and evaluation for seedling emergence and vigor. Crop Sci. 1962, 2, $176-177$. [CrossRef]

41. Ford, R. Demonstrating osmotic potential: One factor in the Plant Water Potential equation. In Tested Studies for Laboratory Teaching, Proceedings of the 36th Conference of the Association for Biology Laboratory Education (ABLE); Article 29; McMahon, K., Ed.; 2015; Volume 36, p. 29. Available online: http:/ / www.ableweb.org/volumes/vol-36/?art=29 (accessed on 17 December 2020).

42. Yamasaki, S.; Dillenburg, L. Measurements of leaf relative water content in Araucaria angustifolia. Rev. Bras. Fisiol. Veg. 1999, 11, 69-75. Available online: https://www.researchgate.net/profile/Lucia_Dillenburg/publication/264876205_Measurements_of_ leaf_relative_water_content_in_Araucaria_Angustifolia/links/551936f50cf21b5da3b7dc75.pdf (accessed on 4 December 2020).

43. Orlovsky, N.; Japakova, U.; Zhang, H.; Volis, S. Effect of salinity on seed germination, growth and ion content in dimorphic seeds of Salicornia europaea L. (Chenopodiaceae). Plant Divers. 2016, 38, 183-189. [CrossRef]

44. Guillén, S.; Terrazas, T.; De la Barrera, E.; Casas, A. Germination differentiation patterns of wild and domesticated columnar cacti in a gradient of artificial selection intensity. Genet. Resour. Crop Evol. 2011, 58, 409-423. [CrossRef]

45. Zhang, H.; Tan, S.N.; Wong, W.S.; Ng, C.Y.L.; Teo, C.H.; Ge, L.; Chen, X.; Yong, J.W.H. Mass spectrometric evidence for the occurrence of plant growth promoting cytokinins in vermicompost tea. Biol. Fert. Soils. 2014, 50, 401-403. [CrossRef]

46. Canellas, L.P.; Lopes-Olivares, F.; Okorokova-Facanha, A.L.; Rocha-Facanha, A. Humic acids isolated from earthworm compost enhance root elongation, lateral root emergence and plasma membrane H+-ATPase activity in maize roots. Plant Physiol. 2002, 130, 1951-1957. [CrossRef] [PubMed]

47. Jeller, H.; Perez, S.C.J.G.A. Effects of water and salt stress and the gibberellin action in Senna spectabilis seeds. Cienc. Florest. 2001, 11, 93-104. [CrossRef]

48. Arancon, N.; Pant, A.; Radovich, T.; Hue, N.V.; Potter, J.K.; Converse, C.E. Seed germination and seedling growth of tomato and lettuce as affected by vermicompost water extracts (Teas). Hort. Sci. 2012, 47, 1722-1728. [CrossRef]

49. Fincher, G.B. Molecular and cellular biology associated with endosperm mobilization in germinating cereal grains. Annu. Rev. Plant Physiol. Plant Mol. Biol. 1989, 40, 305-345. [CrossRef] 
50. Singh, S.; Kulkarni, M.G.; Van Staden, J. Biochemical changes associated with gibberellic acid-like activity of smoke-water, karrikinolide and vermicompost leachate during seedling development of Phaseolus vulgaris L. Seed Sci. Res. 2014, $24,63-70$. [CrossRef]

51. Ayala, F.; O'Leary, J. Growth and physiology of Salicornia bigelovii Torr. at suboptimal salinity. Int. J. Plant. Sci. 1995, 156, 197-205. Available online: www.jstor.org/stable/2474958 (accessed on 4 December 2020). [CrossRef]

52. Kudo, N.; Fujiyama, H. Responses of halophyte Salicornia bigelovii to different forms of nitrogen source. Pedosphere 2010, 20, 311-317. [CrossRef]

53. Haque, M.I.; Rathore, M.S.; Gupta, H.; Jha, B. Inorganic solutes contribute more than organic solutes to the osmotic adjustment in Salicornia brachiata (Roxb.) under natural saline conditions. Aquat. Bot. 2017, 142, 78-86. [CrossRef]

54. Ermakov, E.I.; Ktitorova, I.N.; Skobeleva, O.V. Effect of humic acid in the mechanical properties of cell walls. Rus. J. Plant Physiol. 2000, 47, 518-525.

55. Benazzouk, S.; Djazouli, Z.E.; Lutts, S. Vermicompost leachate as a promising agent for priming and rejuvenation of salt-treated germinating seeds in Brassica napus. Commun. Soil Sci. Plan. 2019, 11, 1344-1357. [CrossRef]

56. Sakakibara, H. Cytokinins: Activity, biosynthesis and translocation. Ann. Rev. Plant Biol. 2006, 57, 431-449. [CrossRef] [PubMed]

57. Ungar, I.A. Halophyte seed germination. Bot. Rev. 1978, 44, 233-264. [CrossRef]

58. Rueda-Puente, E.O.; García-Hernández, J.L.; Preciado-Rangel, P.; Murillo-Amador, B.; Tarazón-Herrera, M.A.; Flores-Hernández, A.; Holguin-Peña, J.; Aybar, A.N.; Barrón Hoyos, J.M.; Weimers, D.; et al. Germination of Salicornia bigelovii ecotypes under stressing conditions of temperature and salinity and ameliorative effects of plant growth-promoting bacteria. J. Agron. Crop Sci. 2007, 193, 167-176. [CrossRef] 